\title{
MENGEMBANGKAN KEMAMPUAN SPASIAL SISWA MELALUI PENDEKATAN SAINTIFIK DALAM PEMBELAJARAN MATEMATIKA
}

\author{
Elly Anjarsari \\ ellyanjar@yahoo.com \\ Pendidikan Matematika, Fakultas Keguruan dan Ilmu Pendidikan, Universitas Islam Lamongan
}

\begin{abstract}
ABSTRAK
Kajian ini dibuat dengan tujuan mengetahui bagaimana pendekatan saintifik diaplikasikan dalam pembelajaran matematika pada proses mengembangkan kemampuan spasial. Pada pendekatan ini siswa diberi kebebasan untuk merencanakan aktivitas belajar dan mencari berbagai sumber belajar yang dapat diperoleh diluar kelas. Dalam pendekatan saintifik yang terdapat pada kurikulum 2013 mencakup beberapa aktivitas belajar, yaitu mengamati, menanya, menalar, mencoba, dan mengkomunikasikan. Diharapkan dengan menggunakan pendekatan saintifik para peserta didik mampu menghasilkan ide kreatif dan inovatif, terutama dalam membantu mengembangkan kemampuan spasial mereka. Hasil kajian menunjukkan pendekatan saintifik dapat membantu siswa mengembangkan kemampuan spasial dan memberi rangsangan kreativitas dan kemandirian siswa dalam menentukan suatu pengetahuan yang baru.
\end{abstract}

Kata Kunci: Kemampuan Spasial, Pendekatan Saintifik, Pembelajaran Matematika

\section{PENDAHULUAN}

Pendidikan adalah hak setiap warga Negara. Setiap warga berhak mendapatkan pendidikan yang layak tanpa membedakan suatu apapun itu. Dengan adanya pendidikan, maka kualitas sumber daya manusia meningkat. Jadi, pendidikan merupakan modal utama yang sangat berperan dalam pembangunan era sekarang ini. Untuk mewujudkannya, dilakukan berbagai upaya yang digunakan untuk meningkatkan kualitas yang meliputi proses kegiatan dan hasil belajar peserta didik. Saat ini upaya dalam mencapai hal tersebut telah dilakukan, diantaranya dengan menyempurnakan dan menerapkan kurikulum baru, pelatihan dan peningkatan kualifikasi guru, penyediaan alat belajar, memperbaiki sarana prasarana, perbaikan sistem pembelajaran serta meningkatkan mutu dan manajemen sekolah.

Banyak sekali fakta di lapangan bahwa masih terdapat adanya guru yang menggunakan metode konvensional atau ceramah dalam kegiatan pembelajaran.
Guru belum melaksanakan kewajiban maupun fungsinya sesuai ketentuan dan tuntutan yang berlaku. Terkadang juga masih ditemukan guru yang enggan dalam pembuatan rancangan pelaksanaan pembelajaran dan metode yang digunakan terlalu monoton, sehingga membuat peserta didik merasakan kejenuhan tanpa adanya semangat dalam mengikuti kegiatan pembelajaran. Akhirnya menyebabkan pembelajaran menjadi kurang efektif dan efisien.

Guru dituntut untuk kreatif dan aktif dalam membuat dan melaksanakan rancangan kegiatan pembelajaran. Salah satu tujuan pembelajaran yang aktif adalah ketika kegiatan berlangsung mampu merespon kebutuhan setiap peserta didik. Dibutuhkan variasi metode pengajaran maupun media pendukung dalam proses pembelajaran.

Saat ini salah satu pendekatan yang tepat digunakan adalah pendekatan saintifik. Pendekatan saintifik adalah proses pembelajaran yang dirancang sedemikian rupa agar peserta didik secara 
aktif mengkonstruk konsep, hukum, dan prinsip melalui tahapan-tahapan mengamati (untuk mengidentifikasi atau menemukan masalah), merumuskan masalah, mengajukan atau merumuskan hipotesis, mengumpulkan data dengan berbagai teknik, menganalis data, menarik kesimpulan dan mengkomuniksikan konsep, hukum, atau prinsip yang ditemukan (Hosnan, 2014:34). Diharapkan dalam pembelajaran saintifik ini, dapat mendorong peserta didik agar lebih aktif dalam mencari tahu berbagai sumber informasi dengan melalui kegiatan observasi, sehingga bukan sekedar dari apa yang sudah diberi tahu oleh guru.

Masih ada faktor lain yang menjadi salah satu peyebab rendahnya siswa dalam prestasi belajar yaitu kemampuan spasial. Kemampuan spasial itu sendiri merupakan kemampuan individu untuk melihat dan membayangkan benda-benda ruang dengan hanya membuat gambar-gambar benda ruang tersebut diatas kertas (Nila Kurniyawati \& N. Setyaningsih, 2013). Banyak siswa yang kesulitan untuk bisa memahami bangun geometri, sehingga diharapkan para guru untuk bisa memberikan perhatian yang lebih agar siswa dapat memecahkan soal-soal dalam dimensi tiga. Pada materi-materi soal dimensi tiga ini hanya bisa divisualisasikan atau digambarkan dalam bentuk dimensi dua. Oleh karena itu, sangat dibutuhkan imajinasi dan daya pikir yang tinggi terhadap keruangan.

Berdasarkan latar belakang diatas maka perlu adanya diterapkan suatu pendekatan pembelajaran yang tepat dan menyenangkan sehingga dapat mengatasi permasalahan dalam mengembangkan kemampuan spasial siswa. Dengan menggunakan pendekatan pembelajaran yang menarik maka siswa akan lebih mudah dalam memahami pelajaran dan mengembangkan kemampuan berpikir spasialnya. Untuk itu kajian ini bertujuan menggambarkan deskripsi pendekatan saintifik dalam mengembangkan kemampuan spasial siswa.

\section{METODE}

Penelitian ini menggunakan pendekatan kualitatif, dengan menekankan pada proses pengumpulan komparasi serta analisis terhadap dinamika hubungan fenomena yang diamati dengan menggunakan logika ilmiah (Saifuddin, 2001:5). Dalam penelitian ini menggunkan jenis penelitian atau research kepustakaan untuk menggali konsep spasial dengan menggunakan pendekatan spasial dalam pembelajaran matematika. Penelitian pustaka adalah serangkaian kegiatan yng berkenaan dengan metode pengumpulan data pustaka, membaca dan mencatat serta mengelola bahan koleksi perpustakaan tanpa memerlukan riset lapangan (Zed, 2004:3).

\section{PEMBAHASAN}

\section{Kemampuan Spasial}

Salah satu aspek dari kognisi adalah kemampuan spasial. Piaget \& Inhelder (1971) menyebutkan bahwa kemampuan spasial sebagai konsep abstrak yang didalamnya meliputi hubungan spasial (kemampuan untuk mengamati hubungan posisi objek dalam ruang), kerangka acuan (tanda yang dipakai sebagai patokan untuk menentukan posisi objek dalam ruang), hubungan proyektif (kemampuan untuk melihat objek dari berbagai sudut pandang), konservasi jarak (kemampuan untuk memperkirkaan jarak antara dua titik), representasi spasial (kemampuan untuk merepresentasikan hubungan spasial dengan memanipulasi secara kognitif), rotasi mental (membayangkan perputaran objek dalam ruang).

Menurut Yilmas (dalam Ahmad, 2015) Spasial merupakan kata serapan bahasa inggris dari spatial dan kata spatial berasal dari kata space yang berarti ruang. 
Kemampuan spasial sering disamakan artinya dengan berbagai frasa seperti keahlian spasial, kemampuan visualisasi, kemampuan visual-spasial, persepsi spasial, kemampuan spasial konseptual, visualisasi dimensi tiga, dan kognisi visual. Kemampuan spasial erat hubungannya dengan kegiatan seharihari.Kemampuan spasial juga berkaitan dengan kemampuan menangkap warna, arah, dan ruang secara akurat. Menurut Amstrong bahwa anak yang cerdas dalam visual-spasial memiliki kepekaan terhadap warna, garis-garis, bentuk-bentuk ruang, dan bangunan (Musfiroh, 2004).

$$
\text { Menurut Gunawan (dalam }
$$

Manurung, 2013:15) ciri-ciri siswa yang memiliki kecerdasan spasial yang berkembang dengan baik adalah: (a) belajar dengan cara melihat dan mengamati, mengenali wajah, objek, bentuk dan warna; (b) mampu mengenali suatu lokasi dan mencari jalan keluar; (c) mengamati dan membentuk gambaran mental, berpikir dengan menggunakan gambar; (d) senang belajar dengan grafik, peta, diagram, atau alat bantu visual; (e) suka mencoret-coret, menggambar, melukis, dan membuat patung; (f) suka menyusun dan membangun permainan tiga dimensi; (g) mempunyai kemampuan imajinasi; (h) mampu melihat sesuatu dengan perspektif yang berbeda; (i) mampu menciptakan representasi visual atau nyata dari suatu informasi; (j) tertarik menerjuni karier, desainer, pilot, perancang pakaian, dan karier lain yang banyak menggunakan visual.

Pada penelitian ini menggunakan teori Haas untuk mendeskripsikan karakteristik kecerdasan spasial siswa. Karakteristik siswa dengan menggunakan kecerdasan spasial menurut Haas (dalam Ningsih, Sriwahyu dan Budiarto, Mega Teguh, 2014 : 205-206) yaitu: pengimajinasian, pengkonsepan, memecahkan masalah, dan pencarian pola.

Tabel indikator kecerdasan spasial

\begin{tabular}{lll}
\hline Indikator & Keterangan \\
\hline Pengimajinasian & $>\begin{array}{l}\text { Siswa dapat menyajikan informasi } \\
\text { maupun gambar yang relevan } \\
\text { dengan permasalahan. }\end{array}$ \\
$>$ & $\begin{array}{l}\text { Siswa mampu mengungkapkan } \\
\text { alasan dari informasi maupun } \\
\text { gambar yang telah disajikan. }\end{array}$ \\
\hline Pengkonsepan & Siswa dapat menentukan konsep \\
& permasalahan dan mengaitkannya \\
& dengan pengetahuan sebelumnya. \\
& $\begin{array}{l}\text { Siswa mampu menjelaskan alasan } \\
\text { dalam menentukan konsep dari } \\
\text { materi yang telah disajikan. }\end{array}$ \\
\hline Memecahkan & $\begin{array}{l}\text { Siswa dapat menentukan cara yang } \\
\text { akan digunakan untuk } \\
\text { menyelesaikan permasalahan. }\end{array}$ \\
$>$ & $\begin{array}{l}\text { Siswa mampu menyelesaikan } \\
\text { permasalahan yang ada sesuai } \\
\text { dengan cara yang telah ditentukan. }\end{array}$ \\
& $\begin{array}{l}\text { Siswa mampu menjelaskan alasan } \\
\text { memilih menggunakan cara tersebut } \\
\text { dalam penyelesaian masalah. }\end{array}$ \\
\hline
\end{tabular}

Hubungan Antara kemampuan spasial dengan matematika

Didalam kemampuan spasial diperlukan adanya pemahaman kiri kanan, pemahaman perspektif, bentuk-bentuk geometris, menghubungkan konsep spasial dengan angka, kemampuan dalam metransformasi mental dari bayangan 
visual. Diantara faktor-faktor tersebut juga diperlukan dalam belajar matematika. Menurut Hamley (dalam McGee, 1979) kemampuan matematika adalah gabungan dari intelegensi unum, pembayangan visual, kemampuan untuk mengamati angka, konfigurasi spasial dan menyimpan konfigurasi sebagai pola mental. Smith (1980) menyimpulkan bahwa antara kemampuan spasial dengan konsep matematika taraf tinggi terdapat hubungan yang positif, tetapi kurang mempunyai hubungan dengan perolehan konsepkonsep matematika taraf rendah seperti hitungan.

Metode pengajaran matematika yang memasukkan berpikir spasial seperti bentuk-bentuk geometris, mainan (puzzle) yang menghubungkan konsep spasial dengan angka, menggunakan tugas-tugas dapat membantu terhadap pemecahan masalah dalam matematika (Newman, dalam Elliot, 1987). Selain itu terdapat pengertian lain terhadap konsep pembagian, proporsi tergantung dari pengalaman spasial yang mendahuluinya (Clements, dalam Elliot, 1987).

\section{Pendekatan Saintifik}

Berdasarkan Peraturan Menteri Pendidikan dan Kebudayaan Republik Indonesia Nomor 65 Tahun 2013 tentang Standar Proses Pendidikan Dasar dan Menengah dapat dinyatakan bahwa sasaran pembelajaran mencakup pengembangan ranah sikap, pengetahuan, dan ketrampilan yang dicapai dengan menggunakan pendekatan ilmiah (scientific), tematik terpadu (tematik antar mata pelajaran), dan tematik (dalam suatu mata pelajaran), pembelajaran berbasis penelitian (inquiry learning), dan pembelajaran yang menghasilkan karya berbasis pemecahan masalah (problem based learning).

Menurut Permendikbud Nomor 81

A Tahun 2013 tentang Implementasi Kurikulum lampiran IV, proses pembelajaran terdiri atas lima pengalaman belajar pokok yaitu: (1) mengamati, melalui kegiatan belajar yang dilakukan dalam proses mengamati adalah membaca, mendengar, menyimak, melihat (tanpa atau dengan alat). Kompetensi yang dikembangkan adalah melatih kesungguhan, ketelitian, dan mencari informasi; (2) menanya, melalui kompetensi yang dikembangkan adalah mengembangkan kreativitas, rasa ingin tahu, dan kemampuan merumuskan pertanyaan untuk membentuk pikiran kritis yang perlu untuk hidup cerdas dan belajar sepanjang hayat; (3) mengumpulkan informasi/eksperimen merupakan kegiatan pembelajaran yang berupa eksperimen, membca sumber lain selain bukuteks, mengamati objek/kejadian/aktivitas, dan wawancara dengan narasumber; (4) mengasosiasi/mengolah informasimerupa-kan kegiatan pembelajaran yang berupa pengolahan informasi yng sudah dikumpulkan baik terbatas dari hasil kegiatan mengumpulkan/eksperimen maupun hasil dari kegiatan mengamati dan kegiatan mengumpulkan informasi; mengkomuni-kasikanmerupakan kegiatan pembelajaran yang berupa menyampaikan hasil pengamatan, kesimpulan berdasarkan hasil analisis secara lisan, tertulis, atau media lainnya.

Daryanto (2014:51) mengungkapkan bahwa pembelajaran dengaan pendekatan saintifik adalah proses pembelajaran yang dirancang sedemikian rupa agar peserta didik secara aktif mengkonstruksi konsep, hukum tau prinsip melalui tahapan tahapan mengamati, merumuskan masalah, mengajukan atau merumuskan hipotesis, mengumpulkn data dengan berbagai teknik, menganalisis data, menaarik kesimpulan dan mengkomunikasikan konsep, hukum atau prinsip yng ditemukan.

Berdasarkan pendapat ahli diatas dapat disimpulkan bahwa pendekatan 
saintifik adalah suatu pendekatan dimana proes pembelajaran berpusat kepada peserta didik, dimana tugas guru adalah membimbing. Dengan semakin berkurangnya bantuan guru dalam proses pembelajaran, sehingga semakin bertambah dewasanya peserta didik, karena guru memberikan masalah berdasarkan dunia nyata/fenomena yang terjadi dikehidupan peserta didik, sehingga peserta didik mencoba mencari jawaban masalah yang telah diberikan guru secara mandiri. Pesert didik diharapkan terampil dalam menerapkan pengetahuannya dalam kehidupan.

Proses dalam mengembangkan kemampuan spasial siswa, diperlukan materi yang bisa dihubungkan dengan kehidupan sehari-hari. Salah satunya adalah materi bangun ruang sisi datar yang diperoleh pada semester genap kelas 2 SMP. Dintaranya indikator materi tersebut adalah menyelesaikan permasalahan yang berhubungan dengan volume balok dan kubus. Siswa membutuhkan ketajaman berpikir abstrak dan pengimajinasian dalam menyelesaikan permasalahan tersebut. Diharapkan dengan melalui pendekatan saintifik siswa mampu memunculkan rasa suka dan ketertarikan dengan matematika. Sehingga sudah tidak ada lagi isu bahwa matematika merupakan pelajaran yang sulit dan membosankan.

\section{Mengembangkan Kemampuan Spasial melalui Pendekatan Saintifik}

Kemampuan spasial siswa diperlukan terutama dalam memecahkan suatu masalah yang berhubungan dengan geometri. Siswa kesulitan mengerjakan permasalahan yang berhubungan dengan bangun ruang. Terkadang dalam menggambar dari arah sisi depan, kanan, kiri, dan belakang mereka masih kesulitan. Sehingga diperlukan suatu pendekatan yang mampu membuat siswa dalam memahami pengimajinasian.
Dalam pendekatan saintifik matematika, terjadi pada setiap tahapan kemampuan spasial. Berdasarkan pendapat beberapa ahli mengenai tahapan pendekatan sintifik, disimpulkan bahwa tahap pendekatan saintifik diantaranya yang pertama: adalahmengamati, dimana kegiatan belajar yang dilakukan dalam proses mengamati adalah membaca, mendengar, menyimak, melihat (tanpa atau dengan alat). Dengan tujuan adalah melatih kesungguhan, ketelitian, dan mencari informasi. Proses kemampuan spasial yang terjadi pada tahapan ini adalah pengimajinasian, dengan siswa dapat menyajikan informasi maupun gambar yang relevan dengan permasalahan. Siswa mampu mengungkapkan alasan dari informasi maupun gambar yang telah disajikan.

Kedua, menanya. Kompetensi yang dikembangkan adalah mengembangkan kreativitas, rasa ingin tahu, dan kemampuan merumuskan pertanyaan untuk membentuk pikiran kritis yang perlu untuk hidup cerdas dan belajar sepanjang hayat. Proses kemampuan spasial yang terjadi adalah pengimajinasian, dengan siswa dapat menyajikan apa yang akan ditanyakan dari informasi maupun gambar yang relevan dengan permasalahan. Dalam tahapan ini siswa akan merencanakan suatu pertanyaan dengan mengacu pada tujuan menjawab rasa keingin tahuan untuk berpikir kritis.

Ketiga, mengumpulkan informasi. Dengan melakukan kegiatan pembelajaran yang berupa eksperimen, membaca sumber lain selain buku teks, mengamati objek/kejadian/aktivitas, dan wawancara dengan narasumber. Proses kemampuan spasial yang terjadi adalah pengkonsepan, dimana siswa dapat menggunakan suatu konsep dan menjelaskan alasan dalam menentukan konsep untuk menyelesaikan permasalahan dengan cara bereksperimen, mengamati dan mewawancara. 
Keempat dan kelima diantaranya adalah dengan melakukan pengolahan informasi yang sudah dilakukan dan mengkomunikasikan hasil pengamatan berupa kesimpulan baik secara lisan maupun tertulis. Proses kemampuan spasial yang terjadi pada langkah keempat dan kelima adalah pemecahan masalah, dimana siswa mampu memilih cara, menyelesaikan masalah, dan mampu menjelaskan cara yang dipilih dalam menyelesaikan masalah tersebut melalui presentasi.

Untuk mengembangkan kemampuan spasial peserta didik diperlukan pendekatan saintifik 5M. Dalam pemdekatan ini menempatkan peserta didik sebagai subyek yang diberikan kebebasan dalam menentukan pemahaman menurut pengalaman dan penemuan sehingga dapat memunculkan suatu konsep.Dalam kegiatan pembelajaran ini guru hanya sebagai pembimbing atau fasilitator, yang mempunyai fungsi memberikan semangat dan dorongan dalam memahami apa yang peserta didik butuhkan.

\section{KESIMPULAN}

Berdasarkan analisis diatas maka penulis merumuskan beberapa kesimpulan sebagai tindak lanjut dari artikel ini, yaitu: (1) Dalam pembelajaran matematika diperlukan adanya kemampuan spasial yang tinggi, yaitu dengan cara menghubungkan antara satu konsep dengan konsep matematika lainnya. Untuk membantu siswa dalam mengatasi kesulitannya maka diperlukan suatu pendekatan yang benar, cepat, dan tepat. Salah satunya yaitu pendekatan saintifik dengan beberapa langkah yang dapat memudahkan siswa dalam menemukan sesuatu yang baru; (2) Pendekatan saintifik merupakan pendekatan yang dalam pelaksanaannya berdasarkan petunjuk dari guru. Guru hanya membimbing dan sebagai fasilitator jika diperlukan saat siswa mengalami hal yang kurang dipahami. Dalam pendekatan ini siswa didorong untuk berfikir hingga menemukan penyelesaian sendiri.

\section{DAFTAR PUSTAKA}

Daryanto, (2013)

Pendekatan

Pembelajaran

Saintifik

Kurikulum 2013. Jakarta: Gava Media.

Eliot, J. 1987. Model of Psychological Space: Psychometric,

Developmental and Experimental Approaches. New York: Springer-Verlag.

Guay, R. dan E. McDaniel. 1977. The Relation between Math Achievement and Spatial Abilities among Elementary School Children. Journal of Research in Mathematics Education, 7, halaman: 211-215.

Kemendikbud. (2013).Konsep Pendekatan Scientific. Bahan Pelatihan, Jakarta: Kementerian Pendidikan dan Kebudayaan RI.

McGee, M.F. 1979. Human Spatial Ability: Psychometric Studies and Environment: Genetic, Hormonal, and Neurological Influences. Psychological Bulletin, 5, halaman: 887-902.

Peraturan Menteri Pendidikan dan Kebudayaan Republik Indonesia Nomor 65 Tahun 2013 tentang Standar Proses Pendidikan Dasar.

Peraturan Menteri Pendidikan dan Kebudayaan Republik Indonesia Nomor 81 A Tahun 2013 tentang Implementasi Kurikulum.

Piaget, J. dan Inhelder, B. 1971. Mental Imagery in Child. New York: Basic Books.

Saifuddin, Azmar, 2001. Metode penelitian. Jogjakarta: Pustaka Pelajar. 
Reforma: Jurnal Pendidikan dan Pembelajaran

Vol. 7 No. 2 (2018)

p-ISSN: 2503-1228; e-ISSN: 2621-4172

Sani, R.A. (2014).Pembelajaran Saintifik

Zedmestika, 2004. Metode penelitian untuk Implementsi Kurikulum 2013. Jakarta: PT Bumi Aksara.

Smith, P.K. 1980. Spatial Ability. London: University of London Press. kepustakaan. Jakarta: Yayasan Bogor Indonesia. 